\title{
Money Laundering Risk Evaluation of Financial Institution with AHP Model
}

\author{
Muhammad Subtain Raza, Muhammad Fayaz, Muhammad Haseeb Ijaz, Danish Hussain, \\ Sana Rubab
}

National Bank of Pakistan, Lahore, Pakistan

Email: sibtain1232@gmail.com

How to cite this paper: Raza, M. S., Fayaz, M., Ijaz, M. H., Hussain, D., \& Rubab, S. (2017). Money Laundering Risk Evaluation of Financial Institution with AHP Model. Journal of Financial Risk Management, 6, 119-125.

https://doi.org/10.4236/jfrm.2017.62010

Received: October 15, 2016

Accepted: June 9, 2017

Published: June 12, 2017

Copyright $\odot 2017$ by authors and Scientific Research Publishing Inc. This work is licensed under the Creative Commons Attribution International License (CC BY 4.0).

http://creativecommons.org/licenses/by/4.0/

\begin{abstract}
Money laundering risk assessment is a primary tool to combat the perils of money laundering. This study is based on a model of risk assessment, which assists the management of financial institution to evaluate the range and level of money laundering risk (MLR). In this model, MLR is primarily divided into two risk levels, i.e. Inherent Risk \& Control Risk with their auxiliary subdivisions. Analytic Hierarchy Process (AHP) software assists in its computations and provides for pairwise weights and comparisons. By using this model, money laundering risk of a financial institution could be assessed.
\end{abstract}

\section{Keywords}

Evaluation, Money Laundering Risks, Analytic Hierarchy Process

\section{Introduction}

Financial Institutions encompass a wide range of financial products and services, which are associated with different money laundering risks. To combat these risks financial institutions review, assess and weigh inherent risks; allocate their compliance resources, organize their internal controls and internal structures, and implement policies and procedures to deter and detect money laundering aspects (FATF, 2014).

Currently, the world's AML regulatory approach is conducted in two ways: "rule- based" and "risk-based". As pioneers in the field of AML, the UK and the USA are gradually moving toward implementing the "risk-based" AML regulatory approach. In identifying and assessing the money laundering risks to which they are exposed, banks should consider a range of factors which may include: the nature, scale, diversity and complexity of their business; their target markets; customers, jurisdictions, distribution channels, the internal audit and regulatory 
findings; the volume and size of its transactions, considering the usual activity of the bank and the profile of its customers. Adequate internal controls are a prerequisite for the effective implementation of policies and processes to mitigate $\mathrm{ML} / \mathrm{TF}$ risk. Internal controls include appropriate governance arrangements where responsibility for AML/CFT is clearly allocated, controls to monitor the integrity of staff, in accordance with the applicable local legislation, especially in cross-border situations and the national risk assessment, compliance and controls to test the overall effectiveness of the bank's policies and processes to identify, assess and monitor risk. Money Laundering Risks = Money Laundering Inherent Risk $\times$ Money Laundering Control Risk (FATF, 2014).

Inherent risks include: Clients, Products and Services, Channels, Geographies, other Qualitative Risk Factors. Control risks comprise of AML Corporate Governance; Management Oversight and Accountability, Policies and Procedures, Know Your Client ("KYC"); Client Due Diligence (“CDD”); Enhanced Due Diligence ("EDD”), Previous Other Risk Assessments (local and enterprise-wide), Management Information/Reporting, Record Keeping and Retention, Designated AML Compliance Officer/Unit, Detection and SAR filing, Monitoring and Control, Training, Independent Testing and Oversight (including recent Internal Audit or Other Material Findings), Other Controls/Others (The Wolfsberg Group, 2015).

Money laundering risks of an institution vary based on many parameters namely: institution size, internal rules, management attitude, and so on. Various researchers have conducted the assessment of money laundering risks by scoring the opinion of field experts or professionals e.g., reviewers (Cai \& Liu, 2011). It has been proved that involved risk factors are distinct from each other in their natures and weights. To examine the issue, professionals and managers are asked to make inherent risk and control risk assessments on cases (Wang \& Yang, 2007).

An improved AHP method was proposed to provide exact assessments for improving acquirement of weights of each risk factor to avoid some qualitative methods such as expert scoring. Then, combining of the characteristic of risk assessment framework of bank information system, the proposed fuzzy-AHP method was applied to obtain weights of each risk factor of bank information system. Decisions involve many intangibles that need to be traded off. To do that, they have to be measured alongside tangibles whose measurements must also be evaluated as to, how well they serve the objectives of the decision maker. The Analytic Hierarchy Process (AHP) is a theory of measurement through pairwise comparisons and relies on the judgements of experts to derive priority scales (Saaty, 1990).

Researchers pointed out that reviewers can raise the examining factors, and also concluded that the inherent relationship of these factors, which could then be analysed using Analytic Hierarchy Process (Saaty, 1990), the weight of each factors as well as reasonable marks, could be obtained. Identification of money laundering risks factors and constructing money laundering risks structure have 
been complicated for assessors and researchers worldwide; the key elements composing money laundering risks are complicated (IIROC, 2010).

This research focuses on a money laundering risks assessment model which proves a handy source for reviewers to evaluate and compare the money laundering risks of financial institutions. The basic task is to find the most significant risk factors and institute a logical money laundering risks assessing model.

\section{Methodology}

Analytic Hierarchy Process (AHP), is a model proposed by Thomas L. Saaty (1970), a model by which complex issues can be structured and analyzed by hierarchical division, and subjective decision according to objective conclusions would be made.

The analytical hierarchy process (AHP), a hierarchically layered structure, was developed for decision making. This paper proposes a model that applies AHP to a network knowledge management platform. We then explain how AHP can be utilized on money laundering risks. We then present the results of a specially designed questionnaire that we administered to fifteen experts. Finally, we present the weights for the money laundering risks.

Following consideration was kept in mind while formulating money laundering risks; Money Laundering Risks $=$ Money Laundering Inherent Risk $\times$ Money Laundering Control Risk. Goepel, K. D. (2013) devised Excel software to implement the analytic hierarchy process as a standard method for multi-criteria decision making in corporate enterprises. We have used Goepel's version 04.05.2016 for multi-criteria decision making. 15 Experts were requested to accord their valuable assessments.

\section{Scales}

Intensities $\mathrm{x}$, with $\mathrm{x}=1$ to 9 (integer) are transformed into $\mathrm{c}$ using following relations:

1- Linear $\mathrm{c}=\mathrm{x}$

$\mathrm{n}$ is then used as element in the pair-wise comparison matrix.

$\mathrm{n}=$ Numbers of criteria $=10$.

$\mathrm{N}=$ Number of Participants $=15$.

$\alpha=$ Consistency Acceptance $=0.1$.

\section{Division of Money Laundering Risks into Hierarchy of Factors}

For the assessment of money laundering risks, supervisors and management teams divide money laundering risks (MLR) of a financial institution into two sections, viz. Inherent Risk (IR) and Control Risk (CR), which may be tagged as the second level of this AHP model.

Inherent Risk (IR): Inherent risk is the vulnerability of a financial institution to money laundering which bear inherent and environmental characteristics. Inherent risk involves numerous elements among which the following four are the most considerable. 
The size of the institution $\left(I R_{1}\right)$ A larger \& multi-national bank has a higher susceptibility of being exploited in laundering money than a smaller $\&$ indigenous bank. Although the measurements of institution size are various (e.g. by asset, capital, revenue, profit, employee number or branch number, etc.), the number of customers is the most relevant indicator in analyzing the interaction between size and MLR of an institution because all money launderings are eventually committed by "customers", and thus could be used here to define the size of institution (The Wolfsberg Group, 2015).

The geographic location of the institution $\left(I R_{2}\right)$. This element basically intents the location, area and business vicinity of customers. Institutions operating in the regions with high crime rate would face more potential money-launderers and thus have higher MLR (Federal Financial Institutions Examination Council, 2010).

Correspondent banking $\left(I R_{3}\right)$. CB is the provision of banking services by one bank (the "correspondent bank") to another bank (the "respondent bank"). Large international banks typically act as correspondents for thousands of other banks around the world. Correspondent banking is vulnerable to money laundering for two main reasons: By their nature, correspondent banking relationships; The amount of money that flows through correspondent Accounts (FATF, 2016).

The business nature of the institution $\left(I R_{4}\right)$ : Institutions with high proportion of cash deposit or withdrawal, cross-border wire transfer and non-face-to-face businesses are normally more vulnerable to money laundering (Council of Europe, 2010).

Control Risk (CR): CR is the risk that money laundering may occur and not be prevented or detected on a timely basis by the internal control structure of the institution. CR is identified by the factors with indigenous approach of institution and manageable by the institution itself.

Our study followed the four basic factors which directly interferes the CR levels and from which other inside factors are derived (Ma, 2009).

Management attitude and knowledge $\left(C R_{5}\right)$. In this approach expert evaluators assess the senior executives' attitude and knowledge about AML by interviewing the executives as well as the employees or by checking the written responsibilities of the executives (Jia et al., 2013).

Procedures and measures $\left(C R_{6}\right)$. Expert evaluators can assess the validity of the AML procedures and measures in an institution by off-site reviews (Jia et al., 2013).

Computer system $\left(C R_{7}\right)$. The two core roles that the computer system is expected to play in the AML structure of an institution are storing customer identification information and transaction records and analyzing abnormal transactions. On-site test is needed to assess the efficiency of the AML computer system in an institution (Jia et al., 2013).

Performance of customer due diligence $\left(C R_{8}\right)$. On-site inspection is needed to assess whether the performance of customer due diligence regulatory require- 
ments or internal procedures are fully implemented within an institution, including identifying and verifying the identity of the customer and the beneficial owner, recording the basic identity information of the customer (Jia et al., 2013).

Resources allocated $\left(C R_{9}\right)$. The resource allocated in AML can be measured by the total working hours of all AML staff in the institution or the amount of funds spent on AML (Jia et al., 2013).

Trainings $\left(C R_{10}\right)$. To be assessed, conducting direct insightful discussions (Jia et al., 2013).

\section{Pairwise Comparisons and Consolidation of Judgments}

The assessment is based on pair-wise comparisons, the consolidation of all judgments are interpreted by reference tables (random index, limits for geometric consistency index GCI, judgment scales) using the eigenvector method (EVM).

After constructing AHP model, the priorities have been finalized. Elements are compared pair-wise and judgments on comparative attractiveness of elements are captured using the traditional 9 rating scale, with 9 indicating "extreme importance", 7 indicating "very strong or demonstrated importance", 5 indicating "strong or essential importance", 3 indicating "fairly importance", 1 indicating "equal importance" when give the intensity of importance. Scores of $2,4,6,8$ demonstrate intermediate values and reciprocals show inverse comparison (Jia, 2013).

\section{Results and Discussion}

AHP software was used to conduct pair wise comparisons and results were as shown in Table 1 (Jia, 2013).

As expressed by the Table 2, least portion was contributed by inherent risk (IR, 11\%) and most proportion reported by Control risk (CR, 89\%). This concludes and supports the results of (Jia, 2013), so we can predict and re-confirm the findings of (Jia, 2013) that the Money Laundering is basically "controllable" provided that the institution has a strong internal control system. Authorities should thus focus more attentions on the Control risks. Considering the lowest hierarchy of factors, the utmost basic task for a financial institution in lessening and combating money laundering risks is to rigorously focus on management attitude and knowledge $\left(\mathrm{CR}_{5}, 22.0 \%\right)$, meticulous Performance of customer due diligence $\left(\mathrm{CR}_{8}, 18.8 \%\right)$ and Geographic locations $\left(\mathrm{IR}_{2}, 9.2 \%\right)$, Trainings $\left(\mathrm{CR}_{10}\right.$,

Table 1. Contribution of inherent \& control risks to MLR.

\begin{tabular}{|c|c|}
\hline \multicolumn{2}{|c|}{$1^{\text {st }}$ hierarchy } \\
\hline \multicolumn{2}{|c|}{$2^{\text {nd }}$ hierarchy } \\
\hline Inherent Risks (IR) & Control Risk (CR) \\
\hline 0.11 & 0.89 \\
\hline
\end{tabular}


Table 2. Results of pairwise comparisons.

\begin{tabular}{|c|c|c|c|c|c|}
\hline Factors for Risk Assessment & $\begin{array}{c}\text { Weights } \\
\%\end{array}$ & $\begin{array}{l}\text { Normalization } \\
\text { Value }\end{array}$ & $\begin{array}{l}\text { Normalized Principal } \\
\text { Eigenvector }\end{array}$ & Rank & Inherent Risk/Control Risk \\
\hline The size of the institution $\left(\mathrm{IR}_{1}\right)$ & $6.2 \%$ & 0.061689 & $6.17 \%$ & 8 & Inherent Risk \\
\hline $\begin{array}{l}\text { The geographic location of the institution } \\
\qquad\left(\mathrm{IR}_{2}\right)\end{array}$ & $9.2 \%$ & 0.091903 & $9.19 \%$ & 3 & Inherent Risk \\
\hline Correspondent banking $\left(\mathrm{IR}_{3}\right)$ & $7.9 \%$ & 0.078696 & $7.85 \%$ & 6 & Inherent Risk \\
\hline The business nature of the institution $\left(\mathrm{IR}_{4}\right)$ & $6.4 \%$ & 0.063548 & $6.35 \%$ & 7 & Inherent Risk \\
\hline Management attitude and knowledge $\left(\mathrm{CR}_{5}\right)$ & $22.0 \%$ & 0.219868 & $21.99 \%$ & 1 & Control Risk \\
\hline Procedures and measures $\left(\mathrm{CR}_{6}\right)$ & $6.0 \%$ & 0.059922 & $5.99 \%$ & 9 & Control Risk \\
\hline Computer system $\left(\mathrm{CR}_{7}\right)$ & $5.3 \%$ & 0.052663 & $5.27 \%$ & 10 & Control Risk \\
\hline $\begin{array}{l}\text { Performance of customer due diligence } \\
\qquad\left(\mathrm{CR}_{8}\right)\end{array}$ & $18.8 \%$ & 0.188065 & $18.81 \%$ & 2 & Control Risk \\
\hline Resources allocated $\left(\mathrm{CR}_{9}\right)$ & $9.2 \%$ & 0.091823 & $9.18 \%$ & 4 & Control Risk \\
\hline Trainings $\left(\mathrm{CR}_{10}\right)$ & $9.2 \%$ & 0.091823 & $9.18 \%$ & 4 & Control Risk \\
\hline
\end{tabular}

Eigen value $=10.89052$.

9.2\%), Resources allocated $\left(\mathrm{CR}_{9}, 9.2 \%\right)$ and aspect of correspondent banking $\left(\mathrm{IR}_{3}\right.$, $7.9 \%)$ is also significantly important followed by nature of business $\left(\mathrm{IR}_{4}, 6.4 \%\right)$. Procedures and measures $\left(\mathrm{CR}_{6}, 6 \%\right)$ also plays a noteworthy role in assessment of money laundering risks of the institution.

\section{Conclusion}

In this study, money laundering risks were divided into a range of weights of hierarchy of elements. For these computations, AHP software was used. The money laundering risk structures established and created the weights that facilitate to calculate the money laundering risks levels of a financial institution and give insights to financial institutions to oversee their money laundering risks to some extent. Due to continuous development and variability in economies and societies the money laundering risks in financial sector also change, which demands vibrant and flexible money laundering risk evaluation model.

\section{References}

Cai, Y. L., \& Liu, Z. M. (2011). Establishment of Chinese Anti Money Laundering Supervision Mode Drawing on the Experience of UK \& US. In: Research on China's Anti-Money Laundering (pp. 374-376). Beijing: China Financial Publishing House Press.

Council of Europe (2010). Guidelines on Bank Risk Analysis Aimed at Preventing Money Laundering and Terrorism Financing.

FATF (2014). The FATF Recommendations-International Standards on Combating Money Laundering and the Financing of Terrorism \& Proliferation. Paris: FATF.

FATF (2014). Guidance for Risk Based Approach; The Banking Sector. Paris: FATF.

FATF (2016). Guidance on Correspondent Banking Services. Paris: FATF.

Federal Financial Institutions Examination Council (2010). Bank Secrecy Act/AntiMoney Laundering Examination Manual.

http://www.ffiec.gov/bsa aml infobase/pages manual/manual online.htm

Goepel, K. D. (2013). Implementing the Analytic Hierarchy Process as a Standard Me- 
thod for Multi-Criteria Decision Making in Corporate Enterprises-A New AHP Excel Template with Multiple Inputs. Proceedings of the International Symposium on the Analytic Hierarchy Process 2013.

IIROC (Investment Industry Regulatory Organization of Canada) (2010). Anti-Money Laundering Compliance Guidance. Toronto: IIROC.

Jia, K. et al. (2013). Assessing Money Laundering Risk of Financial Institutions with AHP: Supervisory Perspective. Journal of Financial Risk Management, 2, 29-31. http://dx.doi.org/10.4236/jfrm.2013.21004

Ma, J. (2009). Financial Institutions Anti-Money Laundering Practical Manual (pp. 268-276). Beijing: China Financial Publishing House Press.

Saaty, T. L. (1970). How to Make a Decision: The Analytic Hierarchy Process. European Journal of Operational Research, 48, 9-26. http://dx.doi.org/10.1016/0377-2217(90)90057-I

The Wolfsberg Group (2015). Wolfsberg FAQs on Risk Assessments for ML, Sanctions and Bribery \& Corruption. France: The Wolfsberg Group.

Wang, S. N., \& Yang, J. G. (2007). A Money Laundering Risk Evaluation Method Based on Decision Tree. The 6 th International Conference on Machine Learning and Cybernetics, $1,283-286$.

Submit or recommend next manuscript to SCIRP and we will provide best service for you:

Accepting pre-submission inquiries through Email, Facebook, LinkedIn, Twitter, etc. A wide selection of journals (inclusive of 9 subjects, more than 200 journals)

Providing 24-hour high-quality service

User-friendly online submission system

Fair and swift peer-review system

Efficient typesetting and proofreading procedure

Display of the result of downloads and visits, as well as the number of cited articles Maximum dissemination of your research work

Submit your manuscript at: http://papersubmission.scirp.org/

Or contact jfrm@scirp.org 